\title{
ANALYSIS OF WET ACID DEPOSITION IN MACAU
}

\author{
K.I. HOI \\ K.M. MOK* \\ K.V. YUEN
}

Received: 16/12/05

Accepted: 02/05/06

\author{
University of Macau \\ Faculty of Science and Technology \\ Department of Civil and Environmental Engineering \\ Av. Padre Tomás Pereira S.J. \\ Taipa, Macau SAR, China
}

*to whom all correspondence should be addressed: e-mailkmmok@umac.mo

\begin{abstract}
Records of precipitation in Macau are collected from three local monitoring stations from 1993 to 2003. Chemical compositions of precipitation are analyzed to reveal the causes of wet deposition in Macau. The review of annual rainfall volumes and the volume weighted annual $\mathrm{pH}$ values over this period show that there is a slight spatial variation in the rainfall volume and the entire area of Macau is subjected to acidic precipitation. The monthly rainfall volumes and the monthly concentrations of five ionic species including $\mathrm{H}^{+}, \mathrm{nssSO}_{4}{ }^{2-}, \mathrm{NO}_{3}{ }^{-}, \mathrm{nssCa}^{2+}$, and $\mathrm{NH}_{4}{ }^{+}$are analyzed statistically and their distributions are found to have positive skewness and kurtosis. The monthly rainfall volume is found to follow the Gamma distribution which is consistent with the findings in other regions of Asia. In addition, the monthly concentration of each ionic species is found to follow the lognormal distribution. Nonetheless, the distribution of each ionic species exhibits spatial variability across the stations. Therefore, it is suspected that the sources of wet acid deposition in different parts of Macau are different and further correlation analysis on the values of $\left[\mathrm{H}^{+}\right], \mathrm{nss}\left[\mathrm{Ca}^{2+}\right],\left[\mathrm{NH}_{4}^{+}\right], \mathrm{nss}\left[\mathrm{SO}_{4}{ }^{2-}\right]$, and $\left[\mathrm{NO}_{3}{ }^{-}\right]$of the precipitation is carried out.

Correlation analysis on the monthly concentrations of the ionic species shows that the linear correlation between $\left[\mathrm{H}^{+}\right]$and $n s s\left[\mathrm{SO}_{4}{ }^{2-}\right]$ is higher than the linear correlation between $\left[\mathrm{H}^{+}\right]$and $\left[\mathrm{NO}_{3}{ }^{-}\right]$at two of the monitoring stations. The result indicates that sulfur dioxide could be a relatively important contributor of acid wet deposition with respect to nitrogen dioxide in Macau as suggested by previous preliminary studies. In addition, the eleven-year averaged ratio of $\left[\mathrm{SO}_{4}{ }^{2}\right] /\left[\mathrm{NO}_{3}{ }^{-}\right]$at $\mathrm{Ka}$-Ho being 5.06 reinforces this conclusion. However, the dominant sources contributing to the acidity in two regions of Macau, namely Fortaleza and Taipa Grande respectively are still unknown since the anions do not show any significant positive correlation to the hydrogen ion at these two stations. It is only ascertained that the dominant source of acidity in $\mathrm{Ka} \mathrm{Ho}$ can be originated from the emission of $\mathrm{SO}_{2}$ as the relatively strong linear correlation of $\left[\mathrm{H}^{+}\right]$and nss $\left[\mathrm{SO}_{4}{ }^{2-}\right]$ indicates that the free acidity is mainly contributed from the sulfuric acid. For the other stations, the wet acid deposition is then believed to be controlled by local sources of sulfuric acid, nitric acid and some other acids that are not accounted for in the present study. Finally, the monthly concentrations of the ionic species are found to be negatively correlated with the monthly rainfall volume at three monitoring stations. Hence, it is concluded that longer rainfall duration would reduce the acidity in rainwater.
\end{abstract}

KEYWORDS: wet acid deposition, rainfall, $\mathrm{pH}$, ionic species, spatial variability, skewness, kurtosis, cumulative distribution function, correlation, Macau

\section{INTRODUCTION}

Wet acid deposition or acid rain is known to be caused by the presence of the gaseous $\mathrm{SO}_{2}$ and $\mathrm{NO}_{\mathrm{x}}$ in the atmosphere. In the recent decades, wet acid deposition was found to pose many adverse environmental impacts such as the acidification of lakes. With significant relevance to the biosphere, understanding its behavior is crucial for important administrative 
and industrial decision making in a metropolitan area. The rapid growth in economic development and population in Eastern Asia led this region become the third largest acid rain region after Europe and North America [1] and the most severely affected area is at southern part of China [2]. Recent studies on acid rain distribution pattern in China indicate that acidic rainfalls are most frequently observed in south China in deed although the north tends to have stronger $\mathrm{SO}_{2}$ and $\mathrm{NO}_{x}$ emissions. This was found due to the effects of atmospheric aerosol loading, alkaline matter content in soil and meteorological conditions [3]. Macau, a coastal city located in the Pearl River Delta within this region, is growing fast recently and has been paying attention to this phenomenon. Preliminary studies show that the wet deposition in Macau is acidic and the main factor contributes to it may be sulfur dioxide [4], [5], [6]. To verify this claim, a detailed analysis of the rainfall volume and the concentrations of the ionic species including $\left[\mathrm{H}^{+}\right]$, nss $\left[\mathrm{Ca}^{2+}\right],\left[\mathrm{NH}_{4}{ }^{+}\right], \mathrm{nss}\left[\mathrm{SO}_{4}{ }^{2}\right]$, and $\left[\mathrm{NO}_{3}{ }^{-}\right]$are carried out in the present study. The symbol "nss" placed before an ionic species is used to denote the non-seasalt component of the ionic species. To facilitate this, a general overview of the annual rainfall volumes and the $\mathrm{pH}$ values over an eleven-year period from 1993 to 2003 at three monitoring stations are presented, followed by a statistical analysis of the data sampled from each monitoring station. Then, a comparison of the sample statistics and distributions across all these three stations is carried out. Finally, the effect of rainfall on the concentrations of the ionic species will be demonstrated and discussed.

\section{ANNUAL VARIATIONS OF RAINFALL AND pH IN MACAU}

The concern of wet acid deposition in Macau began in 1990, as development in Macau as well as the region was rapid. The Serviços Meteorológicos e Geofísicos de Macau (SMG) started monitoring the rainfall and its chemical composition at two monitoring stations located at Ka-Ho and Fortaleza in 1990. The Ka-Ho station is located at a rural area in Coloane with an elevation of $27 \mathrm{~m}$. The Fortaleza station is located at the top of a hill of peak elevation of $59 \mathrm{~m}$. Later in 1996, the Fortaleza station was relocated to Taipa Grande. The Taipa Grande station is set at the top of a relatively remote hill of peak elevation of $159.2 \mathrm{~m}$. The locations of the stations on the map are shown in Figure 1. Each station is equipped with an automatic rainfall collector with two collecting containers to collect the weekly and monthly rainfall, respectively. The $\mathrm{pH}$ and the weekly rainfall volume are obtained from the weekly collection container, whereas the chemical composition of the rainwater is obtained by analyzing the water sample from the monthly collection container. Weekly $\mathrm{pH}$ and rainfall volume data are available from 1993 to 2003. As more than a decade of data are available, studying the data in the annual time scale would reveal the long-term trend of rainfall and acidity in Macau. Annual rainfall volume and volume weighted annual $\mathrm{pH}$ values are estimated and the time plots of them can be found in Figures $2 \mathrm{a}$ and $2 \mathrm{~b}$. The annual rainfall volume and the annual $\mathrm{pH}$ value at Fortaleza in 1996 are not shown due to the relocation of the station from Fortaleza to Taipa Grande. The annual rainfall volume at the Ka-Ho station shown in Figure 2 a shows a large variation within the last decade. It is noted that the pattern of the time series generally repeats with a period of 3 to 5 years, i.e., each period can be represented by a rise in the rainfall volume, which is followed by a declination in the rainfall volume after the peak occurs. The peaks occur in the years of 1993, 1998 and 2002 respectively. The enhancement of the rainfall volume within each period is possibly associated with the El Nino phenomenon as the years in which the peaks values occur are the onset years of El-Nino or the first year succeeding it. Similar situation is also observed for some neighboring cities in the southern China [8], [9]. For the Fortaleza station and the Taipa Grande station, the rainfall volumes observed at these two stations are slightly higher than the volume observed at the $\mathrm{Ka}-\mathrm{Ho}$ station. However, temporal variations of the annual rainfall volumes at all stations are similar as the size of Macau is indeed small and the slight spatial variability of the rainfall can be caused by the topography of the region in which the station is situated. For the acidity condition of Macau, the $\mathrm{pH}$ values at $\mathrm{Ka}-\mathrm{Ho}$ and Fortaleza shown in Figure $2 \mathrm{~b}$ have a slight trend of decline from 1993 to 1999 meaning that the acidity condition was worsening. Starting from 1999, the annual pH values at Ka-Ho and Taipa Grande show an increasing trend. 


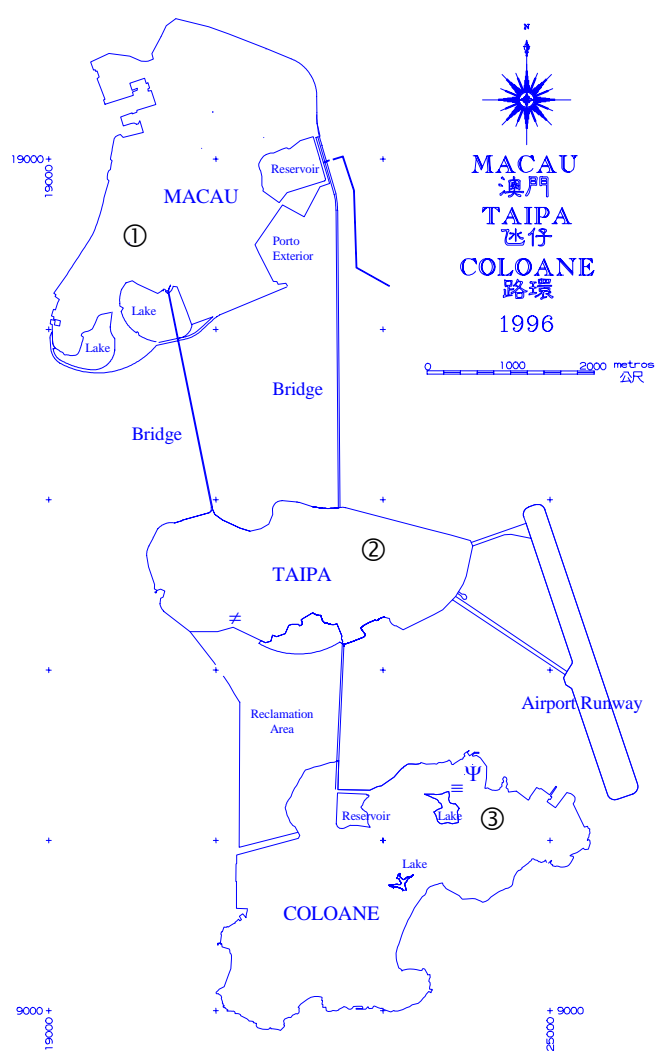

Figure 1. Map of Macau [7] and the location of rainfall monitoring stations; (1)Fortaleza, (2) Taipa Grande, (3) Ka-Ho

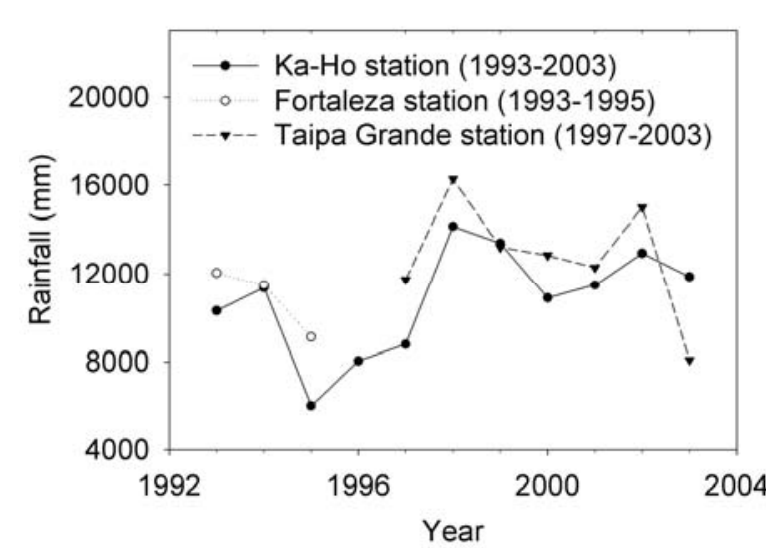

(a)

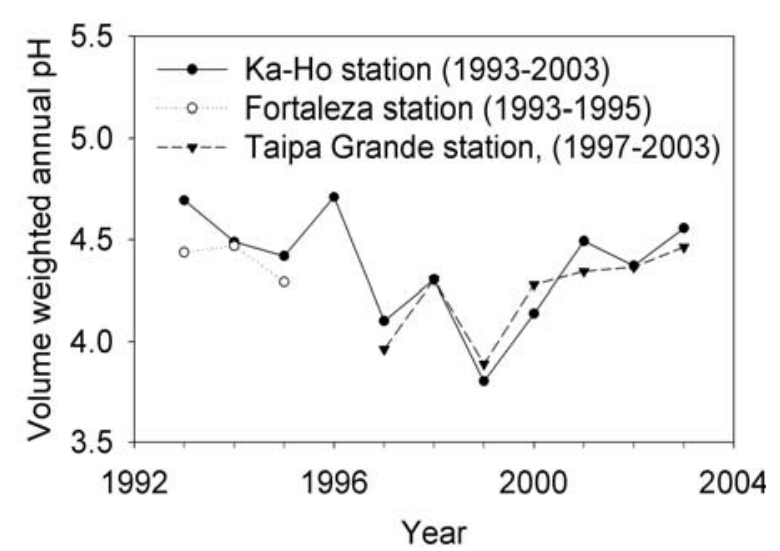

(b)

Figure 2. Annual rainfall volume and $\mathrm{pH}$ at three monitoring stations from 1993 to 2003;

(a) annual rainfall volume, (b) annual $\mathrm{pH}$

Even though the situation of acidity in Ka-Ho and Taipa Grande is improving/increasing gradually starting from 1999, the annual $\mathrm{pH}$ values in all stations are still less than 5.6 (the value for "Clean" or unpolluted precipitation) over the eleven-year period indicating a persistent presence of acid precipitation in the entire area of Macau.

\section{SAMPLE STATISTICS AND DISTRIBUTIONS OF RAINFALL AND IONIC SPECIES}

As illustrated by using the $\mathrm{pH}$ as an indicator of free acidity in the previous section, it is shown that there is a persistent presence of acid precipitation in the entire area of Macau between 1993 and 2003. In the present section, monthly data of rainfall volume and the concentrations of the ionic species including $\left[\mathrm{H}^{+}\right]$, nss $\left[\mathrm{Ca}^{2+}\right],\left[\mathrm{NH}_{4}{ }^{+}\right]$, nss $\left[\mathrm{SO}_{4}{ }^{2}\right]$, and $\left[\mathrm{NO}_{3}{ }^{-}\right]$at three monitoring stations are analyzed so that their basic behaviors in the temporal sense can be characterized in a probabilistic manner. Monthly data are analyzed to allow estimation of the sampling 
distribution and test statistics at different stations. The sampling distribution is represented by the cumulative distribution function (CDF) $F(x)$ which indicates the probability $P(X \leq x)$ where the random variable $X$ is at most equal to a particular value $x$. Figures 3-5 show the cumulative distribution functions of $\left[\mathrm{H}^{+}\right], \mathrm{nss}\left[\mathrm{SO}_{4}{ }^{2-}\right],\left[\mathrm{NO}_{3}{ }^{-}\right], \mathrm{nss}\left[\mathrm{Ca}^{2+}\right],\left[\mathrm{NH}_{4}{ }^{+}\right]$and also the rainfall volume at three monitoring stations. The sample CDF is represented by the staircase plot drawn with solid line in each sub-plot of the figure. To approximate the sample CDF with a continuous CDF, prior knowledge about the shape of the distribution could be obtained through calculations of the sample skewness and kurtosis (Table 1). The skewness indicates whether a distribution is symmetrical about the mean. When it is positive, the distribution is positively skewed or skewed to the right, i.e., the mean is larger than the median. When it is negative, the distribution is negatively skewed or skewed to the left. When the skewness is zero, the distribution is perfectly symmetrical about the mean. The kurtosis indicates the peakedness of the distribution. When it is positive, the distribution is leptokurtic, which means the peakedness of the distribution is greater than that of the normal distribution. When it is negative, the distribution is platykurtic and has the peakedness less than that of the normal distribution. When the kurtosis is zero, the distribution is mesokurtic and its peakedness equals to that of the normal distribution.

Examining the sample skewness shown in Table 1, all the distributions of the ionic species are positively skewed with the minimum value of 1.02 for $\mathrm{nss}\left[\mathrm{SO}_{4}{ }^{2-}\right]$ at Fortaleza between 1993 and 1995, and the maximum value of 8.66 for $\mathrm{nss}\left[\mathrm{Ca}^{2+}\right]$ and $\left[\mathrm{NO}_{3}{ }^{-}\right]$at $\mathrm{Ka}-\mathrm{Ho}$ between 1993 and 2003. The results of kurtosis are similar. All the distributions of the ionic species are leptokurtic with the minimum value of 3.00 for nss[ $\left.\mathrm{SO}_{4}{ }^{2-}\right]$ at Fortaleza, and the maximum value of 84.15 for $\left[\mathrm{NO}_{3}{ }^{-}\right]$at $\mathrm{Ka}-\mathrm{Ho}$. When the test statistics of different ionic species at the same monitoring station are compared, the skewness and kurtosis of nss $\left[\mathrm{Ca}^{2+}\right]$ are generally larger than those of the other ionic species. When the tests statistics of the same ionic species of different stations are compared, the ionic species except for $\left[\mathrm{H}^{+}\right]$at $\mathrm{Ka}-\mathrm{Ho}$ are generally more positively skewed and leptokurtic than those at Fortaleza and the Taipa Grande. As the skewness and kurtosis suggest that the possible continuous probability density function should be positively skewed and leptokurtic, a lognormal distribution is chosen to approximate the sampling distribution. Looking back at Figures 3-5, a lognormal CDF is fitted to each sample CDF of the ionic species with a dotted curve. It is noted that the sample CDFs are well approximated by the lognormal CDF. Therefore, temporal concentrations of the ionic species can be well modeled by lognormal distributions. Although their basic behaviors in the temporal sense are similar, the distribution of each ionic species exhibits spatial variability across the stations as indicated by the variations of skewness and kurtosis shown in Tables 1 and 2.

Table 1. Skewness of the sampling distribution for each monitoring station

\begin{tabular}{lccc}
\hline & $\begin{array}{c}\text { Ka-Ho station } \\
(1993-2003)\end{array}$ & $\begin{array}{c}\text { Fortaleza station } \\
(1993-1995)\end{array}$ & $\begin{array}{c}\text { Taipa Grande station } \\
(1997-2003)\end{array}$ \\
\hline$\left[\mathrm{H}^{+}\right]$ & 2.83 & 1.86 & 3.22 \\
{$\left[\mathrm{NH}_{4}^{+}\right]$} & 5.94 & 2.34 & 2.10 \\
$\mathrm{nss}\left[\mathrm{Ca}^{2+}\right]$ & 8.66 & 3.43 & 7.25 \\
$\mathrm{nss}\left[\mathrm{SO}_{4}{ }^{2-}\right]$ & 5.66 & 1.02 & 2.90 \\
{$\left[\mathrm{NO}_{3}{ }^{-}\right]$} & 8.66 & 3.42 & 3.79 \\
Rainfall & 0.71 & 0.73 & 0.62 \\
\hline
\end{tabular}

Table 2. Kurtosis of the sampling distribution for each monitoring station

\begin{tabular}{lccc}
\hline & $\begin{array}{c}\text { Ka-Ho station } \\
(1993-2003)\end{array}$ & $\begin{array}{c}\text { Fortaleza station } \\
(1993-1995)\end{array}$ & $\begin{array}{c}\text { Taipa Grande station } \\
(1997-2003)\end{array}$ \\
\hline$\left[\mathrm{H}^{+}\right]$ & 11.72 & 6.74 & 14.99 \\
{$\left[\mathrm{NH}_{4}{ }^{+}\right]$} & 47.71 & 8.85 & 7.64 \\
$\left.\mathrm{nss}^{-} \mathrm{Ca}^{2+}\right]$ & 80.34 & 15.39 & 54.03 \\
$\mathrm{nss}\left[\mathrm{SO}_{4}{ }^{2}\right]$ & 36.77 & 3.00 & 11.15 \\
{$\left[\mathrm{NO}_{3}{ }^{-}\right]$} & 84.15 & 13.90 & 21.80 \\
Rainfall & 2.51 & 2.69 & 2.51 \\
\hline
\end{tabular}




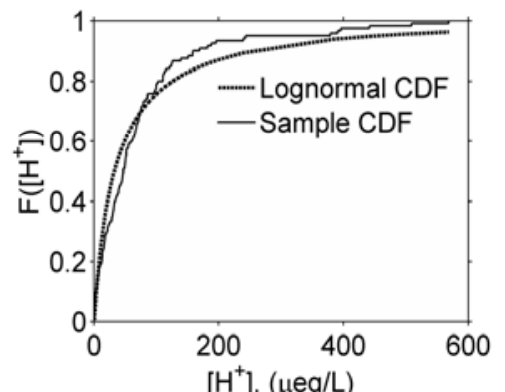

(a)

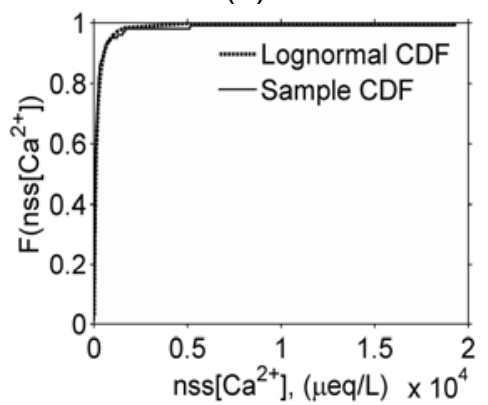

(d)

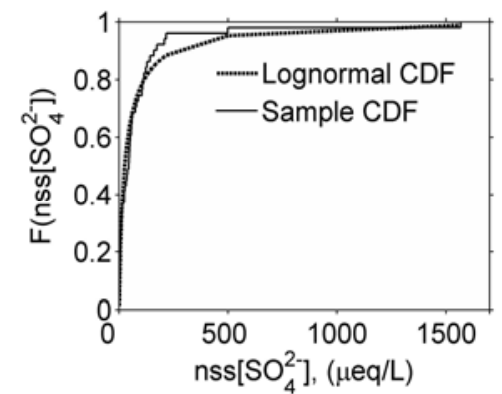

(b)

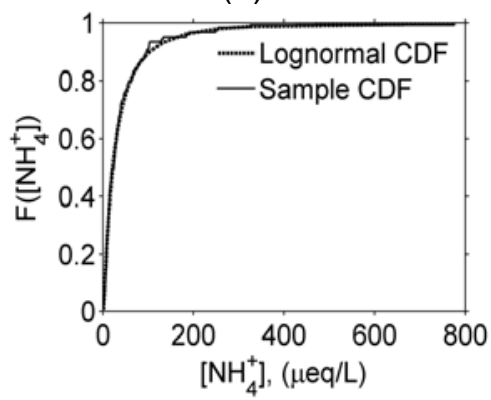

(e)

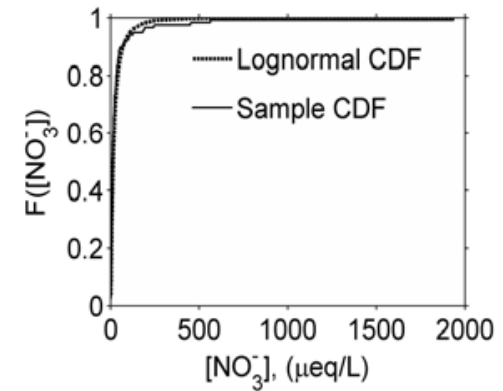

(c)

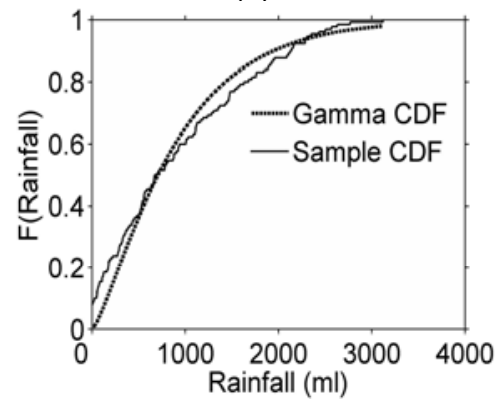

$(\mathrm{f})$

Figure 3. CDFs of samples at Ka-Ho (1993 to 2003); (a) $\left[\mathrm{H}^{+}\right]$, (b) nss[SO $\left.{ }_{4}{ }^{2-}\right]$, (c) $\left[\mathrm{NO}_{3}{ }^{-}\right]$, (d) nss $\left[\mathrm{Ca}^{2+}\right]$, (e) $\left[\mathrm{NH}_{4}^{+}\right]$, (f) Rainfall volume

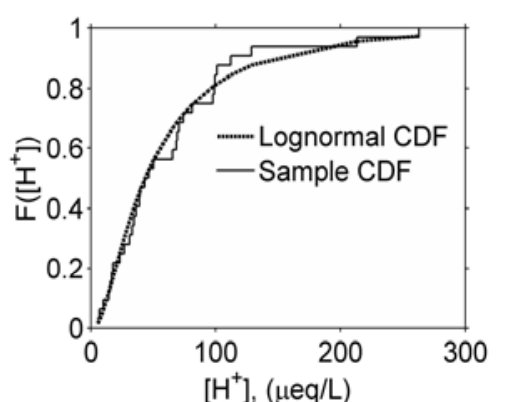

(a)

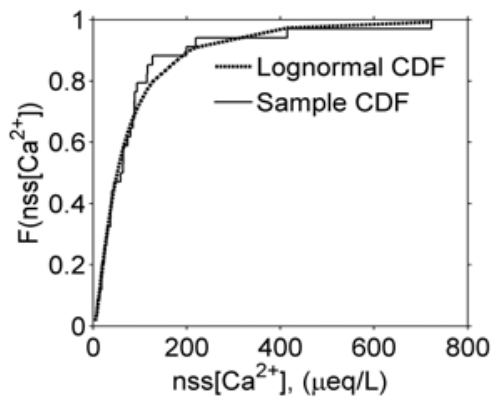

(d)

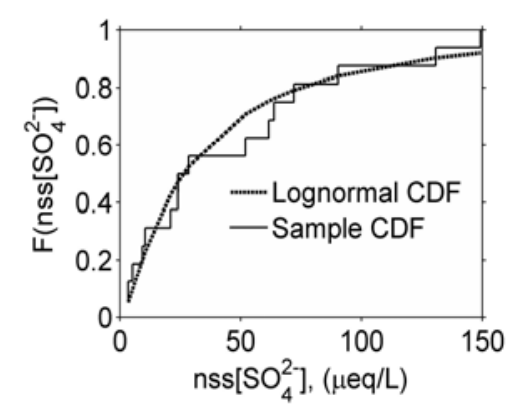

(b)

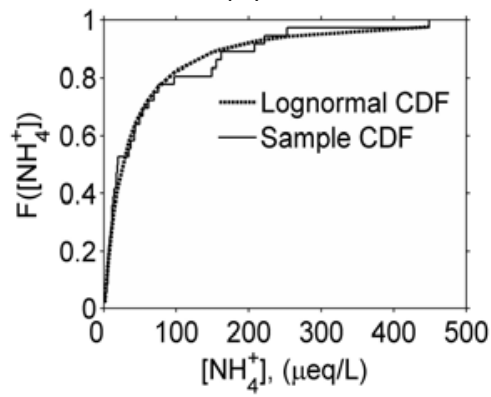

(e)

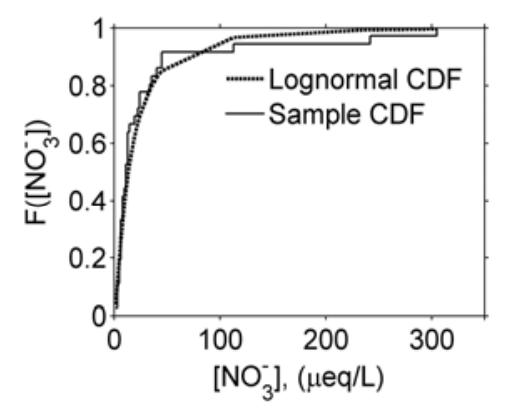

(c)

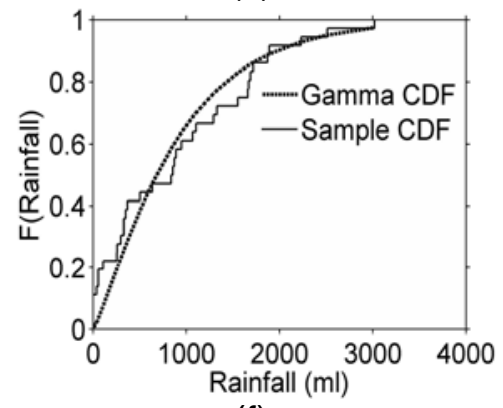

(f)

Figure 4. CDFs of samples at Fortaleza (1993-1995); (a) $\left[\mathrm{H}^{+}\right]$, (b) nss[ $\left[\mathrm{SO}_{4}{ }^{2-}\right]$, (c) $\left[\mathrm{NO}_{3}{ }^{-}\right]$, (d) nss $\left[\mathrm{Ca}^{2+}\right],(e)\left[\mathrm{NH}_{4}{ }^{+}\right]$, (f) Rainfall volume 


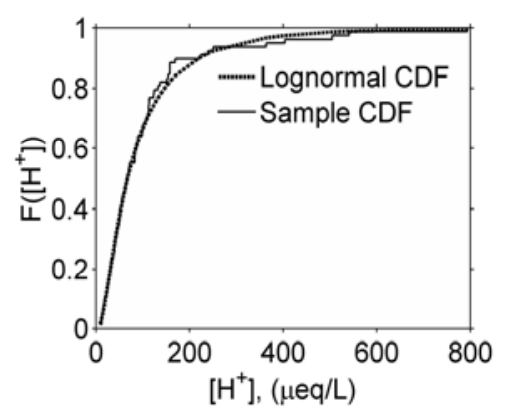

(a)

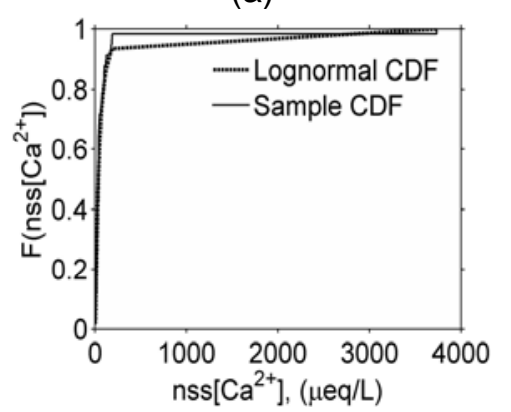

(d)

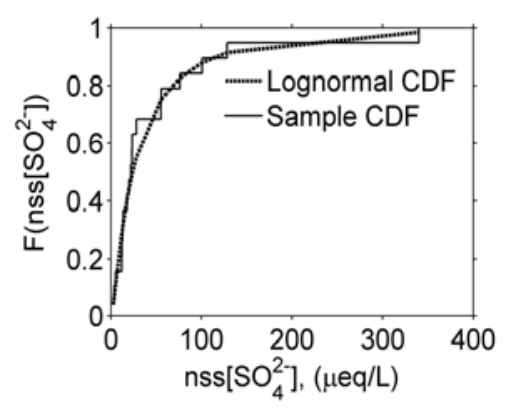

(b)

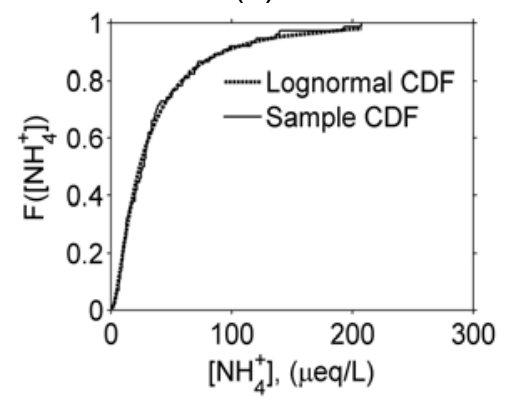

(e)

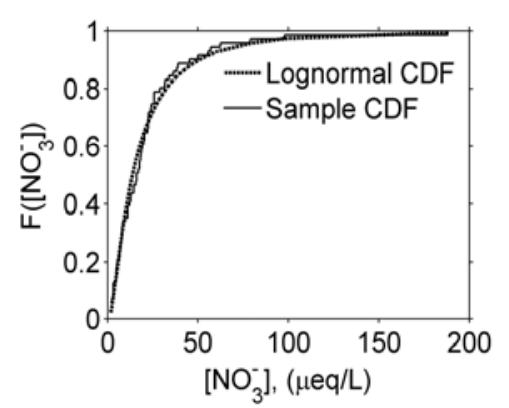

(c)

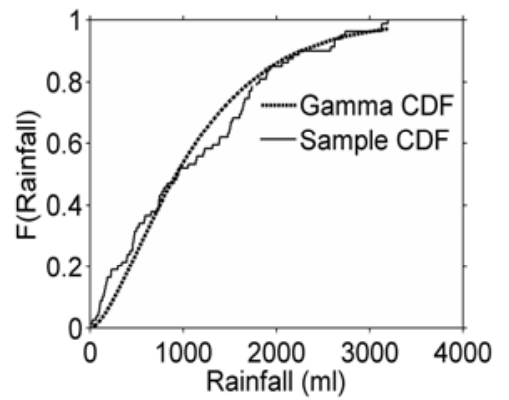

(f)

Figure 5. CDFs of samples at Taipa Grande; (a) $\left[\mathrm{H}^{+}\right]$, (b) nss[SO $\left.{ }_{4}{ }^{2-}\right]$, (c) $\left[\mathrm{NO}_{3}{ }^{-}\right]$, (d) nss[Ca $\left.{ }^{2+}\right]$, (e) $\left[\mathrm{NH}_{4}^{+}\right]$, (f) Rainfall volume

On the contrary, the skewness and kurtosis of the rainfall volume are similar for all the monitoring stations. The similarity of the test statistics among all stations is in good agreement with the slight spatial variability of the annual rainfall volume observed in Figure $2 a$. As the size of Macau $\left(\sim 25 \mathrm{~km}^{2}\right)$ is indeed small, the rainfall pattern should be uniform and hence the slight spatial variation of rainfall should not be the main cause of the spatial variability of the test statistics for the ionic species. Therefore, it is suspected that the sources of wet acid deposition in different parts of Macau are different and this is further investigated through correlation analysis on the values of hydrogen ion $(\mathrm{pH})$, and the other ionic species of the precipitation next. As the distribution of the rainfall volume is positively skewed and leptokurtic, the Gamma CDF is fitted to each sample CDF of the monthly rainfall volume with a dotted curve as shown in Figures 3-5. It is noted that sample CDFs are well approximated by the Gamma CDF. Therefore, temporal variation in the monthly rainfall volume is shown to follow the Gamma distribution. In Asia, the monthly rainfall is shown to follow the Gamma distribution during summer [10]. Therefore, the probability distribution of the rainfall of Macau is consistent with those found for the other regions of Asia.

\section{CORRELATION OF THE IONIC SPECIES}

Through the analysis of the monthly data at different stations in the previous section, test statistics of the ionic species computed at those monitoring stations are found to be different for the same ionic species. The spatial variability of the test statistics suggests that the relative contribution of different types of acids to the free acidity $\left[\mathrm{H}^{+}\right]$can vary in different areas of Macau. Therefore, the linear correlation analysis of $\left[\mathrm{H}^{+}\right], \mathrm{nss}\left[\mathrm{SO}_{4}{ }^{2-}\right]$ and $\left[\mathrm{NO}_{3}{ }^{-}\right]$at three monitoring stations is performed so that the dominant source of acidity in the rainwater among different areas of Macau can be identified. The technique was adopted and shown to be useful in some studies of acid deposition [11], [12]. However, the sulfuric acid or the nitric acid can be neutralized by the alkalinity to form salts, i.e., a large value of nss[ $\left.\mathrm{SO}_{4}{ }^{2-}\right]$ or $\left[\mathrm{NO}_{3}{ }^{-}\right]$ does not necessarily guarantee a large value of $\left[\mathrm{H}^{+}\right]$. Therefore, including the concentrations of the cations which are the nss $\left[\mathrm{Ca}^{2+}\right]$ and the $\left[\mathrm{NH}_{4}^{+}\right]$into the correlation analysis would give better interpretation of the correlation obtained for the hydrogen ion concentrations, and the sulphate ion concentrations, or the nitrate ion concentrations. Table 3 shows the correlation coefficients of the ionic species at the same monitoring station. It is noted that a significant positive correlation exists between $\left[\mathrm{H}^{+}\right]$and $\mathrm{nss}\left[\mathrm{SO}_{4}{ }^{2-}\right]$ at $\mathrm{Ka}-\mathrm{Ho}$ but $\left[\mathrm{H}^{+}\right]$and $\left[\mathrm{NO}_{3}{ }^{-}\right]$are virtually uncorrelated. Since $\mathrm{Ka}-\mathrm{Ho}$ is situated at a rural area with small traffic flow, a power 
plant, however, is located nearby so there is abundant supply of $\mathrm{SO}_{2}$ to form the sulfuric acid. The averaged ratio of nss[ $\left[\mathrm{SO}_{4}{ }^{2}\right] /\left[\mathrm{NO}_{3}{ }^{-}\right]$at $\mathrm{Ka}-\mathrm{Ho}$ between 1993 and 2003 is 5.06 and the high ratio also supports this observation. In addition, the nss $\left[\mathrm{Ca}^{2+}\right]$ and $\left[\mathrm{NH}_{4}^{+}\right]$have significant positive correlation with the $\left[\mathrm{NO}_{3}{ }^{-}\right]$and the nss $\left[\mathrm{SO}_{4}{ }^{2-}\right]$ has moderate positive correlation with the nss $\left[\mathrm{Ca}^{2+}\right]$ and $\left[\mathrm{NH}_{4}{ }^{+}\right]$, which means that a large portion of the nitrate ions is associated with the salts and a large portion of the sulphate is associated with the acidity. Therefore, the contribution of the sulfuric acid to the hydrogen ion formation may overshadow the contribution of the nitric acid there. For the Fortaleza station between 1993 and 1995, moderately positive correlation is found between $\left[\mathrm{H}^{+}\right]$and $n s s\left[\mathrm{SO}_{4}{ }^{2-}\right]$, and weak linear correlation is found for $\left[\mathrm{H}^{+}\right]$and $\left[\mathrm{NO}_{3}{ }^{-}\right]$. In addition, a weak positive linear correlation is found for the $\left[\mathrm{H}^{+}\right]$at both stations. The correlation suggests that the sources of acidity in these two areas are different and a large portion of the hydrogen ions is possibly due to other types of acid other than the sulfuric acid and the nitric acid. As mentioned above, the power plant is located at Coloane, which has a distance of $1 \mathrm{~km}$ away from the Macau peninsula. Although the source of $\mathrm{SO}_{2}$ at the Fortaleza station can be due to the power plant which is shown by a significant positive linear correlation of $\mathrm{nss}\left[\mathrm{SO}_{4}{ }^{2-}\right]$ for $\mathrm{Ka}-\mathrm{Ho}$ and Fortaleza in Table 4, the $\mathrm{SO}_{2}$ emission from the power plant is diluted during the course of transportation to the Macau peninsula. The averaged ratio of nss $\left[\mathrm{SO}_{4}{ }^{2-}\right] /\left[\mathrm{NO}_{3}{ }^{-}\right]$at Fortaleza is 2.35 and it is about $54 \%$ smaller than the ratio observed at $\mathrm{Ka}-\mathrm{Ho}$. The decrease in the ratio of $\mathrm{nss}\left[\mathrm{SO}_{4}{ }^{2-}\right] /\left[\mathrm{NO}_{3}{ }^{-}\right]$is possibly due to the dilution of the $\mathrm{SO}_{2}$. Therefore, it leads to the weakening of the positive linear correlation between $\left[\mathrm{H}^{+}\right]$and nss $\left[\mathrm{SO}_{4}{ }^{2-}\right]$ and the strengthening of the positive linear correlation between $\left[\mathrm{H}^{+}\right]$and $\left[\mathrm{NO}_{3}{ }^{-}\right]$. At this station the nss $\left[\mathrm{Ca}^{2+}\right]$ has a weak positive correlation with the nss $\left[\mathrm{SO}_{4}{ }^{2-}\right]$ and moderate correlation with the $\left[\mathrm{NO}_{3}{ }^{-}\right]$. In addition, the $\left[\mathrm{NH}_{4}{ }^{+}\right]$ has a significant positive correlation with the nss $\left[\mathrm{SO}_{4}{ }^{2-}\right]$ and $\left[\mathrm{NO}_{3}{ }^{-}\right]$respectively. Therefore, a large portion of the sulphate and nitrate ions is associated with salts and it also explains the weakening of the linear correlation between $\left[\mathrm{H}^{+}\right]$and $n s s\left[\mathrm{SO}_{4}{ }^{2}\right]$. For Taipa Grande between 1997 and 2003 , both nss $\left[\mathrm{SO}_{4}{ }^{2-}\right]$ and $\left[\mathrm{NO}_{3}{ }^{-}\right]$are weakly correlated to the $\left[\mathrm{H}^{+}\right]$. As strong positive correlation coefficients shown in Table 4 are obtained for nss[ $\left.\mathrm{SO}_{4}{ }^{2-}\right]$ and $\left[\mathrm{NO}_{3}\right]$ between Ka-Ho and Taipa Grande, similar correlation coefficient should be obtained for $\left[\mathrm{H}^{+}\right]$ as long as sulfuric acid and the nitric acid are the sole sources of acidity in the rainfall. However, the observed correlation coefficient contradicts the assumption and hence it is suspected that other local sources of acids in Taipa Grande are possible. At this station the $\mathrm{nss}\left[\mathrm{Ca}^{2+}\right]$ has a virtual correlation with the nss $\left[\mathrm{SO}_{4}{ }^{2-}\right]$ and moderate correlation with the $\left[\mathrm{NO}_{3}{ }^{-}\right]$. In addition, the $\left[\mathrm{NH}_{4}^{+}\right]$has a significant positive correlation with the nss $\left[\mathrm{SO}_{4}{ }^{2}{ }^{-}\right]$and $\left[\mathrm{NO}_{3}{ }^{-}\right]$ respectively. Therefore, a large portion of the sulphate and nitrate ions is associated with salts and it also explains the weakening of the linear correlation between $\left[\mathrm{H}^{+}\right]$and nss $\left[\mathrm{SO}_{4}{ }^{2}\right]$. Finally, significant positive linear correlation is found for $n s s\left[\mathrm{Ca}^{2+}\right]$ or $\left[\mathrm{NH}_{4}^{+}\right]$among all the monitoring stations. It suggests that the sources that contribute to the nss $\left[\mathrm{Ca}^{2+}\right]$ among different areas of Macau are similar. The case is also similar for $\left[\mathrm{NH}_{4}{ }^{+}\right]$. In the present study, it is suspected that the $\left[\mathrm{NH}_{4}{ }^{+}\right]$is contributed from the dispersion and transformation of ammonia originated from the wastewater treatment plants located in Taipa Grande and Coloane, whereas the nss $\left[\mathrm{Ca}^{2+}\right]$ is associated with the cement company located in Coloane and the building construction activities in different areas of Macau. Through the analysis of the linear correlation of the ionic species, it is found that the characterization of the proportions of sources contributing to the acidity in Macau is difficult since the types of acids contributing to the acidity in some regions are still unknown. It is only ascertained that the dominant source of acidity in $\mathrm{Ka} \mathrm{Ho}$ can be originated from the emission of $\mathrm{SO}_{2}$ as the relatively strong linear correlation of $\left[\mathrm{H}^{+}\right]$and $\mathrm{nss}\left[\mathrm{SO}_{4}{ }^{2-}\right]$ indicates that the free acidity is mainly contributed from the sulfuric acid. In the following section, another parameter which can influence the acidity concentration will be introduced and discussed.

\section{EFFECT OF RAINFALL VOLUME ON THE CONCENTRATIONS OF IONIC SPECIES}

The rainfall in the atmosphere can be viewed as a group of particle collectors. Therefore, their amount which is indicated by the rainfall volume should affect the concentrations of the ionic species in the rainwater. 
Table 3. Correlation coefficients of $\left[\mathrm{H}^{+}\right]$, nss $\left[\mathrm{SO}_{4}{ }^{2-}\right]$, $\left[\mathrm{NO}_{3}{ }^{-}\right]$, nss $\left[\mathrm{Ca}^{2+}\right]$, and $\left[\mathrm{NH}_{4}{ }^{+}\right]$

\begin{tabular}{|c|c|c|c|}
\hline & $\begin{array}{c}\text { Ka-Ho } \\
(1993-2003)\end{array}$ & $\begin{array}{c}\text { Fortaleza } \\
(1993-1995)\end{array}$ & $\begin{array}{c}\text { Taipa Grande } \\
\text { (1997-2003) }\end{array}$ \\
\hline$\left[\mathrm{H}^{+}\right]$and $\mathrm{nss}\left[\mathrm{SO}_{4}{ }^{2-}\right]$ & 0.70 & 0.37 & -0.11 \\
\hline$\left[\mathrm{H}^{+}\right]$and $\left[\mathrm{NO}_{3}\right]$ & -0.09 & 0.17 & 0.19 \\
\hline $\mathrm{nss}\left[\mathrm{Ca}^{2+}\right]$ and $\mathrm{nss}\left[\mathrm{SO}_{4}{ }^{2-}\right]$ & 0.37 & 0.06 & 0.08 \\
\hline $\mathrm{nss}\left[\mathrm{Ca}^{2+}\right]$ and $\left[\mathrm{NO}_{3}{ }^{-}\right]$ & 0.94 & 0.37 & 0.34 \\
\hline$\left[\mathrm{NH}_{4}^{+}\right]$and nss $\left[\mathrm{SO}_{4}{ }^{2-}\right]$ & 0.59 & 0.79 & 0.67 \\
\hline$\left[\mathrm{NH}_{4}^{+}\right]$and $\left[\mathrm{NO}_{3}^{-}\right]$ & 0.85 & 0.86 & 0.62 \\
\hline
\end{tabular}

Table 4. Correlation coefficients of $\left[\mathrm{H}^{+}\right]$, nss $\left[\mathrm{SO}_{4}{ }^{2-}\right]$, $\left[\mathrm{NO}_{3}{ }^{-}\right], \mathrm{nss}\left[\mathrm{Ca}^{2+}\right]$, and $\left[\mathrm{NH}_{4}{ }^{+}\right]$among different stations

\begin{tabular}{lcc}
\hline & $\begin{array}{c}\text { Ka-Ho and Fortaleza } \\
(1993-1995)\end{array}$ & $\begin{array}{c}\text { Ka-Ho and Taipa Grande } \\
(1997-2003)\end{array}$ \\
\hline$\left[\mathrm{H}^{+}\right]$ & 0.19 & 0.61 \\
$\mathrm{nss}\left[\mathrm{SO}_{4}{ }^{2-}\right]$ & 0.90 & 0.97 \\
{$\left[\mathrm{NO}_{3}{ }^{-}\right]$} & 0.42 & 0.88 \\
$\left.\mathrm{nss}^{2} \mathrm{Ca}^{2+}\right]$ & 0.82 & 0.98 \\
{$\left[\mathrm{NH}_{4}{ }^{+}\right]$} & 0.62 & 0.68 \\
\hline
\end{tabular}

To verify this claim, correlation analysis of the concentrations of the ionic species and the rainfall volume is carried out. Figure 6 shows scatter-plots of the logarithmic monthly concentrations of the ionic species and the rainfall volume at Ka-Ho between 1993 and 2003. It is interesting to note that all the species are negatively correlated with the rainfall volume. The negative linear correlation coefficient ranges between -0.20 and -0.63 . As large daily rainfall volumes are observed in summer and the rainfall duration usually lasts for a few hours, the accumulated concentrations of the ionic species are washed out within the first hour and their concentrations are reduced significantly for the following hours of rainfall. Therefore, small daily concentrations of ionic species are usually associated with long duration of rainfall. In addition, the frequency of rainfall also tends to increase with the rainfall volume. As the ambient air is washed out more frequently with a long duration, the probability for small daily concentration to occur becomes higher. Therefore, the averaged monthly concentration of the ionic species generally decreases with the monthly rainfall volume as shown in Figure 6. This is also true for the observations at Taipa Grande and Fortaleza and plots of them are not shown here.

\section{CONCLUSION}

The review of annual rainfall volume and $\mathrm{pH}$ values over the three monitoring stations in the period from 1993 to 2003 shows that the spatial distribution of rainfall among different areas of Macau is uniform and acid precipitation occurs over the entire area of Macau. The monthly rainfall volume and the monthly concentrations of five ionic species $\left[\mathrm{H}^{+}\right], \mathrm{nss}\left[\mathrm{Ca}^{2+}\right],\left[\mathrm{NH}_{4}^{+}\right]$, nss $\left[\mathrm{SO}_{4}{ }^{2-}\right]$, and $\left[\mathrm{NO}_{3}{ }^{-}\right]$in the rainwater are analyzed statistically. The resulting CDFs show that the monthly rainfall volume and the monthly concentrations are governed according to the Gamma distribution and the lognormal distribution respectively. From the correlation analysis of the ionic species, it is found that the sources of wet acid deposition exhibit spatial variability; the wet acid deposition in Macau is controlled by local sources of sulfuric acid, nitric acid and some other acids which are not accounted for in the present study. Finally, it is found that the concentrations of the ionic species are negatively correlated with the monthly rainfall volume at three monitoring stations. Hence, it is concluded that longer rainfall duration would reduce the acidity in rainwater. 


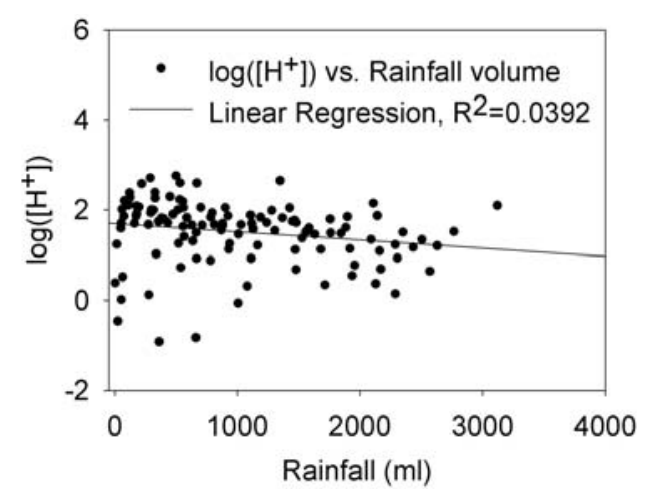

(a)

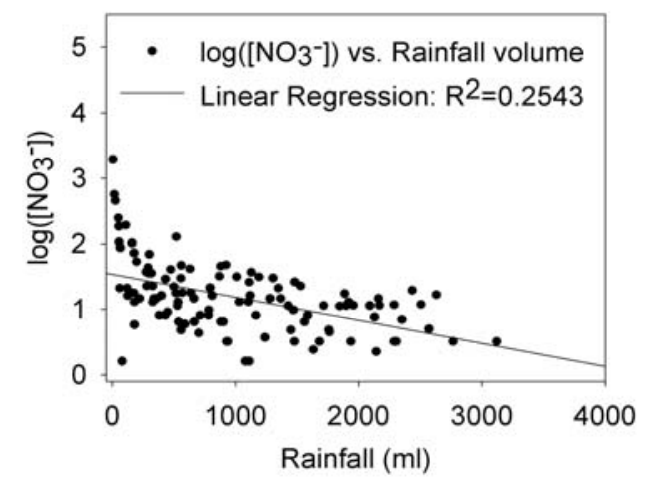

(c)

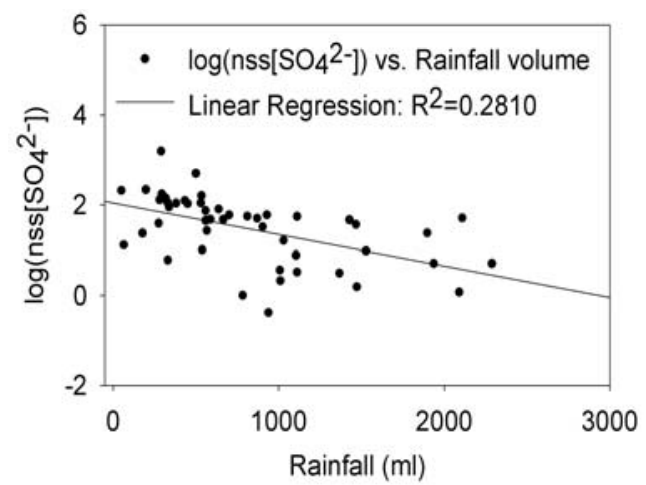

(b)

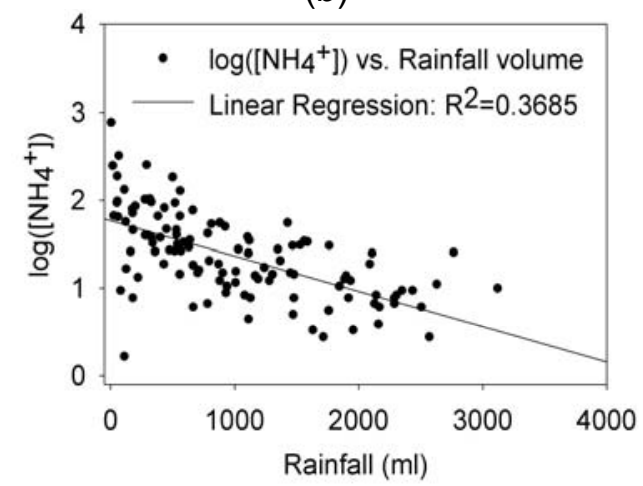

(d)

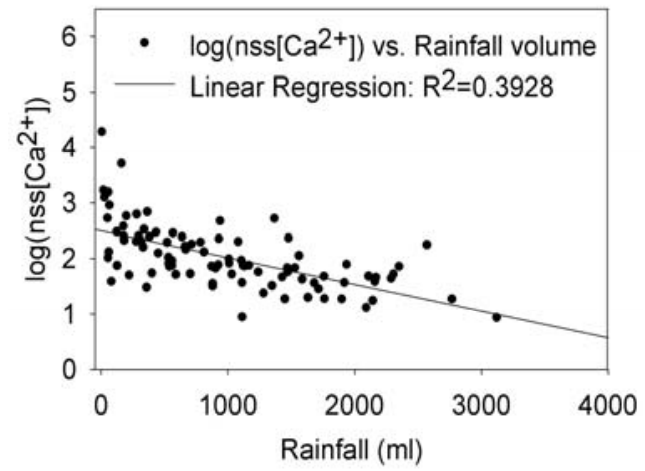

(e)

Figure 6. Scatter plots for the logarithmic monthly concentrations of the ionic species versus the monthly rainfall volume at $\mathrm{Ka}-\mathrm{Ho}$

\section{ACKNOWLEDGEMENT}

This study is supported by the Research Committee of University of Macau (RG070/0405S/MKM/FST). The SMG of Macau is thanked for supplying the data.

\section{REFERENCES}

1. Dovland, H. (1993) EMEP - the European Monitoring and Evaluation Programme, Proc. Expert Meeting on Acid Precipitation Network in East Asia, Toyama, Japan, 34-35.

2. Wang, W., Zhang, W., Hong, X. and Shi, Q. (1993) Study on Factors Related to Acidity of Rain Water in China, J. China Envir. Sci. (in Chinese), 13, 401-407.

3. Wang, W. and Wang, T. (1996) On Acid Rain Formation in China, Atmospheric Environment, 30, 4091-4093.

4. Tam, K.W., Lei, C.S., Young, S.M. Choi, W.W., Chen, W.J. and Chan, S.K. (1994) Acid Rain in Macau (1990-1992), Journal of Macau Studies, 2, 69.

5. Chan, S.K. (1997) The Acid Rain in Macau, The Environmental Protection of Macau (In Chinese), Ed. by Wong, C.S. and Lei, K.P., Macau Foundation, Macau, 71-85. 
6. Chan, S.K., Wang, Z. and Ip, W.F. (1999) Wet Acid Deposition of Macau (1990-1997), Proceedings of the 1st Macau Symposium on Environment and City Development, Macau, 68-77.

7. DSCC (1996) Digital Base Map of Macau's Territory (CD-ROM), Direcção dos Serviços de Cartografia e Cadastro.

8. Chang, W.L. (1999) Some Impacts of El Niño and La Niña Events on the Weather of Hong Kong, Workshop on the Impact of the El Nino Southern Oscillation (ENSO) / La Nina on Meteorology and Hydrology in the Typhoon Committee Area, Macau.

9. Huang, R. and Wu, Y. (1989) The Influence of ENSO on the Summer Climate Change in China and its Mechanisms, Advances in Atmospheric Sciences, 6, 21-32

10. Mooley, D.A. (1973) Gamma Distribution Probability Model for Asian Summer Monsoon Monthly Rainfall, Monthly Weather Review, 101, 160-176.

11. Okay, C., Akkoyunlu, B.O. and Tayanç, M. (2002) Composition of Wet Deposition in Kaynarca, Turkey, Environmental Pollution, 118, 401-410.

12. Sequeira, R. and Lai, C.C. (1998) Small-Scale Spatial Variability in the Representative Ionic Composition of Rainwater within Urban Hong Kong, Atmospheric Environment, 32, 133-144. 